ARTICLE

\title{
The efficiency of public expenditure on Higher Education: a study with Brazilian Federal Universities*
}

\author{
David Daniel Hammes Junior a \\ Leonardo Flach ${ }^{b}$ \\ Luísa Karam de Mattos ${ }^{c}$
}

\section{Abstract}

This study aims to describe the determining factors in efficiency of public expenditures in Brazilian Federal Universities. A two-stage survey method was applied for a sample of fifty-nine Brazilian Federal Universities, from 2013 to 2017. The Data Envelopment Analysis (DEA) was applied for the first stage in order to measure the efficiency of public expenditures. For the second stage, a truncated regression model was applied, with a double bootstrap procedure for bias correction and statistical significance test of the variables. Results show that some Brazilian Federal Universities were inefficient during this period. Considering the truncated regression model of Simar and Wilson (2007), significant variables that influence the efficiency of public expenditures in federal universities were: public expenditures in Higher Education, number of professors, amount of enrolments, amount of graduates, total expenditures with employees and total amount of employees. Therefore, this study has contributed to scientific literature showing that these variables play a key role to public efficiency in federal universities.

Keywords: Efficiency of Public Expenditures. Double Bootstrap. Higher Education. Data Envelopment Analysis. Truncated Regression.

\section{Introduction}

The search for increased efficiency in public expenditures gains importance in academic discussions and in society, due to factors such as: restriction of

\footnotetext{
* Acknowledgment: We thank the National Institute of Science and Technology (CNPq) in Brazil for financial support.

a Faculty of Technology Nova Palhoça/Unigranrio, Palhoça, SC, Brazil.

b Federal University of Santa Catarina, Florianópolis, SC, Brazil.

c Federal University of Santa Catarina, Florianópolis, SC, Brazil.
} 
macroeconomic policies; limits on increase of public expenses; development of globalization and competition with the free market; emergence of new laws that established more transparency in public finances. Hence, demands in the public sector have increased, and they require better quality in public management.

When discussing the efficiency of public spending, this article can be considered an evaluation study. Moreover, the discussion regarding efficiency in the public sector has increasingly become a ground for debate and interest of public managers. The efficiency of public resource allocation to Higher Education is an internationally discussed issue (COCO; LAGRAVINESE, 2014; CUELLAR, 2014; DUFRECHOU, 2016; GRALKA, 2018; MIKUŠOVÁ, 2017; SAV, 2017).

Public policies that are more efficient reduce restrictions in public budget, in order to achieve the same results with fewer resources or, better yet, improving results of current investments (DUFRECHOU, 2016).

Public expenditures may yield different results in growth and development of nations, depending on how they are allocated, either due to bad public management of resources or other factors related to Education systems. Education only yields social and economic benefits when it is developed with a certain degree of quality (COCO; LAGRAVINESE, 2014).

Evaluating the performance of public entities is a key factor for allocating scarce public resources. Identifying inefficient entities, with issues in allocation of public resources, may be the start of any attempt to improve the development of the public sector (WHEELOCK; WILSON, 2008), to create cultural organizations and practice-based learning (FLACH; ANTONELLO, 2011), situated learning, participation and legitimacy in work practices (GUDOLLE; ANTONELLO; FLACH, 2012.

From the viewpoint of public expenditures in Higher Education, the costs within this sphere of Education are high, as they require a great number of qualified professionals, both in lecturing and in administrative activities. Expenses with human resources comprise a major part of the budgets of federal universities. Universities attain efficiency when they generate scientific and social knowledge, help in the development of society, employ academic teams to engage enrolled students and graduate excellent academic personnel. The efficiency of Higher Education, therefore, relates to the performance of universities in providing knowledge to university students (COCO; LAGRAVINESE, 2014) and to society. 
The international literature features numerous studies that provide into the efficiency of universities in various countries, such as the United States (SAV, 2017), Germany (GRALKA, 2018; KEMPKES; POHL, 2010), Australia (ABBOTT; DOUCOULIAGOS, 2003; WORTHINGTON; LEE, 2008), Canada (ARCELUS; COLEMAN, 1997), England (JOHNES, 2008), Greece (KATHARAKI; JATHARAKIS, 2010).

In Brazil, Gramani and Duarte (2011) evaluated the Educational efficiency considering the relationship between the index of quality in Higher Education (product) and the performance of Basic Education (inputs). They analyzed the educational efficiency of the educational Federal Units in Brazil, linking the performance of Basic Education institutions with the quality achieved by Brazilian Federal Universities. This research brings a new approach to this statistical approach, applying Data Envelopment Analysis and a truncated regression model of Simar and Wilson (2007). Therefore, this research gains relevance for adopting a different and innovative methodological approach for studies of systemic educational evaluation of Higher Education in Brazil.

However, there are no works that have analyzed the efficiency of public expenditure in Brazilian federal universities with the method of this study, which justifies this study. International studies state the relevance of the present subject regarding the efficiency of universities, considering the impact in the economic and social context in which these universities are inserted. In these studies, the most commonly used method for efficiency analysis is the data envelopment analysis (SALERNO, 2006).

In this sense, one way of monitoring public management related to resource allocation is to analyze the efficiency of public expenditure. This analysis allows verification of investment results, improvement in services provided for society and increase of efficiency in the use of public financial resources.

\section{Theoretical Review}

Efficiency consists in optimal combination of inputs and methods required for the production process, as to yield the maximum amount of output as possible. In other words, efficiency is the ability to perform tasks correctly, minimizing the input-output relationship and optimizing resource usage.

The efficiency analysis has been used in Higher Education in order to evaluate the manner in which resources are applied and yielded results. Studies in this area 
provide a relative efficiency index as a result, which represents a comparability measure between results produced by a fixed set of inputs and the results. Thus, the efficiency analysis is not only relevant to scholars. Public managers are also interested, and seek to identify potential key aspects to increase efficiency. In addition, efficiency analyses represent an important method to help in the identification of individual needs, in order to improve results in each university (CUNHA; ROCHA, 2012).

Among the studies that seek to analyze the efficiency of public expenditures in the area of Education, the prevalent scientific method is the Data Envelopment Analysis (DEA). The DEA method was initially developed by Farrel (1957) and consolidated afterwards by Charnes, Cooper and Rhodes (1978) as a non-parametric procedure that compares one decision making unit to an efficient border, using performance indicators.

With the DEA tool, it is possible to estimate efficiency via a linear programming. The reason established to estimate efficiency is through the relationship between input and output data. The result generated is an efficiency score between zero and one; the closest to one, the more efficient this entity or Decision Making Unit (DMU) is (CHARNES; COOPER; RHODES, 1978).

Katharaki and Katharakis (2010) highlight the importance of definition of input and output variables, provided these should be defined in order to reliably express the activities developed in universities. Currently, there is no standard to guide the selection of variables used to measure university efficiency. Usually, input data are classified as human, physical and capital. Output data refer to lecturing and research activities.

With a sample from universities in the United Kingdom, Athanassopoulos and Shale (1997) studied efficiency in a sample of 45 universities. Variables used in the study were: overall academic expenses, number of quitters, number of graduates and research classification. Study results have shown that approximately $24 \%$ of universities are efficient with one model, and $60 \%$ with another model analyzed.

When analyzing the efficiency of Australian university expenditures, Abbot and Doucouliagos (2003) obtained performance uniformity in the entire university system as a result, with a considerably high efficiency level. The authors used the variables: number of scholars, production factor expenditures, value of noncurrent assets, research amount. 
With a sample of 210 universities from eight countries in Europe, Joumady and Ris (2005) have measured, through the DEA method, the differences in efficiency levels in Higher Education expenditures. Three models were estimated in the study, in order to improve performance and efficiency of Education in the universities studied. Results found were widely diversified, and efficiency levels vary depending on the model analysed.

In a study with 112 universities in England, Johnes (2008) has analyzed the efficiency and change in productivity of universities for the periods of 1996/97 to $2004 / 05$. The author considered as variables the amount of undergraduate and graduate students, the academic staff, administrative expenses, expenses with centralized academic services, degrees awarded (undergraduate and graduate) and researches developed. The author observed that the rapid changes in Higher Education might have brought along a positive effect on the production technology, affected by the technical efficiency that may cause an impact on the productivity of universities.

Wolszczak-Derlacz and Parteka (2011) analyzed a sample of 259 universities from seven European countries, within a period from 2001 to 2005. The variables used were graduates, total number of students, financing amounts, academic publications. As a result, the universities analyzed that yielded the most efficient results had a larger number of different departments, a higher proportion of women in the academic staff, a higher percentage of external resources, as well as being the oldest Universities.

Wolszczak-Derlacz (2017) have evaluated the efficiency of North American and European universities throughout a decade. As an evaluation method, authors used the DEA method with different sets of input and output. In addition, authors examined the factors that weighed in the inefficiency of these Universities. Results indicate a positive association between regional Gross Domestic Product (GDP) and the number of departments. On average, older European institutions are the most efficient. However, this statement does not apply to North American Universities. In addition, regarding financing, the study pointed out that the public budget had a negative effect on the efficiency of European universities, which cannot be stated about the North American Universities.

Sav (2017) analyzed the efficiency of Higher Education on public universities of the United States and the effects of government funding for the 2004-2013 period. In order to achieve the objective of the research, the author employed data envelopment analysis. The results of the study suggest that efficiency estimates 
vary widely between universities. Besides, the author observed that the increase of public funding improves the efficiency of Higher Education.

Mikušová (2017) has measured the efficiency of public universities in the Czech Republic. The study employed the DEA method, and the variables used were the number of students, quality and performance, number of professors, values related to university funding. The study results enabled the creation of a benchmark, in other words, they showed how much ineffective public universities should change their results in order to become efficient.

Gralka (2018) has analyzed the efficiency analysis limitations for universities, and the method used was a panel data regression model. The variables used refer to number of students, graduates, university financing, expenses, personnel expenditures and number of employees. The study results show that an increase in efficiency for universities is only possible if the measures adopted consider long-term management policies.

\section{Method}

The population approached in this study comprises Brazilian federal universities. According to the Anísio Teixeira National Educational Study and Research Institute (Inep), this amounts to 68 universities. Federal universities created in 2018 were not considered in the research, as they do not feature historical data that substantiate the objective of the study.

It should also be highlighted that universities founded in 2013 (Universidade Federal do Cariri; Universidade Federal do Sul e Sudeste do Pará) and 2014 (Universidade Federal do Oeste da Bahia) were not analyzed, due to insufficient historical data. Universidade Federal do Sul da Bahia, founded in 2011, was also not analyzed in this study, considering that information disclosed in 2013 was insufficient for statistical conclusions. Therefore, the final sample includes 59 federal universities, from a total population of 68 federal universities.

The period analyzed comprises years from 2013 to 2017. The key factor for definition of the period analyzed and federal universities investigated was the presence of data required to achieve the objective of the study.

For the operationalization of the research, secondary data and information from official bodies were collected from the Inep database (http://portal.inep.gov.br/web/ guest/censo-da-educacao-superior, retrieved on December 7, 2018); Transparency 
Portal (http://www.portaltransparencia.gov.br, retrieved on December 7, 2018); in addition, information from management reports of each university was used. The variable public expenditure was restated over the period to approximately maintain actual values.

For all variables used in the research, data refer to undergraduate courses and resources provided by the federal government. The method applied in the research is divided in two different stages. The first stage applied the DEA method, in order to measure the efficiency for the 2013-2017 period. This method is widely used to evaluate the efficiency of allocation of resources applied in Education on federal universities, as it identifies the performance of analysis units and enables comparison between them (JOHNES, 2006; KEMPKES; POHL, 2010; WOLSZCZAK-DERLACZ; PARTEKA, 2011).

In order to carry out the present study, the output-oriented variable returns to scale model (BCC) was considered, as it envisages the oscillation of public resources and size differences in the evaluation process of federal universities (CHARNES; COOPER; RHODES, 1978). Regarding the orientation of the model, Coco and Lagravinese (2014) claim that, within the context of Education, the output orientation is the best choice in order to measure student performance, since emerging countries, such as Brazil, still require improvements in current educational indexes.

The selection of variables defined as inputs and outputs is a complex task, considering there is no standard process for defining such variables. Accordingly, the availability of information and the objectives of the research may be relevant factors in the choice of a set of variables (KATHARAKI; KATHARAKIS, 2010). In face of the importance of the selection of variables, Table 1 features the variables used for application of the DEA method in this research.

Table 1 - Data Envelopment Analysis Model

\begin{tabular}{|c|c|c|c|}
\hline Variables & & Symbol & Description \\
\hline \multirow{2}{*}{ Inputs } & $\begin{array}{l}\text { Public Expenditure } \\
\text { on Education }\end{array}$ & GPE & $\begin{array}{l}\text { Monetary values of direct government } \\
\text { expenditures, in the sub-function Higher Education. }\end{array}$ \\
\hline & $\begin{array}{l}\text { Number of } \\
\text { professors }\end{array}$ & PROF & Number of professors in each federal university. \\
\hline \multirow{2}{*}{ Outputs } & $\begin{array}{l}\text { Service rate in } \\
\text { Higher Education }\end{array}$ & ATEND & $\begin{array}{l}\text { Number of places filled in undergraduate courses } \\
\text { at each federal university. }\end{array}$ \\
\hline & $\begin{array}{l}\text { University } \\
\text { graduates rate }\end{array}$ & CONCL & $\begin{array}{c}\text { Number of graduates in undergraduate courses at } \\
\text { each federal university. }\end{array}$ \\
\hline
\end{tabular}

Source: Own elaboration (2019) 
Public expenditure in Education is used as an input in measuring efficiency. Public expenditure is the most important tool that governments and managers have to expand outputs related to the population's Education level (TADESCO; LOPEZ, 2002). The public expenditure in Education variable was also considered as an input to measure university efficiency in the studies of Abbott and Doucouliagos (2003), Athanassopoulos and Shale (1997), Katharaki and Katharakis (2010) and Worthington and Lee (2008).

Afonso and Fernandes (2008) highlight the importance of analyzing if public expenditure was employed efficiently in a certain department of public administration. The number of professors variable (PROF) is used in the study as an input in the efficiency measurement process. This variable was used in various studies to measure the efficiency in universities, such as the studies from Abbott and Doucouliagos (2003), Afonso and Aubyn (2006), Agasisti and Pérez-Esparrells (2010), Katharaki and Katharakis (2010) an Worthington and Lee (2008). Authors such as Agasisti (2014) and Hanushek and Woessmann (2011) claim that a higher availability of professors causes an increase in number of services in Education, and subsequent lecturing quality.

The service rate in Higher Education (ATEND) is used in the study as an output in measuring efficiency. The educational service rate is considered an important output to be measured, as it is an important factor in order to generate human capital. This variable is important for the analysis of emerging countries, such as Brazil. It is frequently used to identify a government's ability to provide Higher Education to its society (CUELLAR, 2014). The variable was used as output in the studies of Cuellar (2014) in order to evaluate the efficiency of universities.

The university graduates rate (CONCL) is used as a second output in order to measure efficiency of public expenditure in federal universities. The increase in educational service rates assists in the efficient use of expenses. Katharaki and Katharakis (2010) used the number of graduates as an output in order to measure efficiency in universities.

The second stage employs a truncated regression method following the semi-parametric model proposed by Simar and Wilson (2007). The goal is to explain the impact and influence of independent variables in the efficiency 
of public expenditure in Education. According to Simar and Wilson (2007), efficiency scores may be biased within finite samples, as is the case in the present study. The authors also state that efficiency calculation in the standard DEA technique have used, a few years ago, the Tobit regression method in order to calculate inefficiency in a second phase. However, the authors emphasize that, in studies that employ this regression method, yielded results may be biased due to the fact of serial correlation featured between variables in both stages.

Based on the conclusions of Simar and Wilson (2007), this research applied the double bootstrap method. Efficiency scores attained on the first analysis stage were submitted to regression within a set of explanatory variables. The procedure adopted in this study ensures efficient estimates from the estimators of the second stage.

The dependent variable of the regression model is the efficiency score, obtained through the DEA model, calculated in the previous stage of the research. Therefore, for each year analysed, an efficiency score was obtained for each one of the 59 federal universities.

For the regression mode, inputs and outputs used for calculation of efficiency were used as explanatory variables. This way, in addition public expenditures in Education, number of professors, service rate and college graduates rate, the following explanatory variables were used: personnel expenses, number of employees, and investments.

Thus, the following estimated specification is used in the present study to carry out truncated regression for the analysis of efficiency of public expenditure in federal universities.

$\mathrm{EFI}_{\mathrm{it}}=\beta 0+\beta 1 \mathrm{LnGPE}_{\mathrm{it}}+\beta 2 \mathrm{PROF}_{\mathrm{it}}+\beta 3 \mathrm{ATEND}_{\mathrm{it}}+\beta 4 \mathrm{CONCL}_{\mathrm{it}}+\beta 5 \mathrm{LnPESS}_{\mathrm{it}}$ $+\beta 6 \mathrm{FUNC}_{\mathrm{it}}+\beta 7 \mathrm{LnINV}_{\mathrm{it}}+\varepsilon_{\mathrm{it}}$

Equation (1).

Table 2 features the variables used for application of the truncated regression model of Simar and Wilson (2007). 
Table 2 - Simar and Wilson Model (2007)

\begin{tabular}{|c|c|c|c|}
\hline Variables & Symbol & $\begin{array}{l}\text { Expected } \\
\text { Sign }\end{array}$ & Description \\
\hline Efficiency score & $\mathrm{EFI}$ & & $\begin{array}{l}\text { Efficiency score of public expenditure in } \\
\text { Brazilian federal universities (Stage 1). }\end{array}$ \\
\hline $\begin{array}{l}\text { Public expenditures } \\
\text { in Education }\end{array}$ & LnGPE & + & $\begin{array}{l}\text { Natural logarithm of the monetary values of } \\
\text { direct government expenditures, in the Higher } \\
\text { Education subfunction. }\end{array}$ \\
\hline $\begin{array}{l}\text { Number of } \\
\text { Professors }\end{array}$ & PROF & + & Number of professors in each federal university. \\
\hline $\begin{array}{l}\text { Service rate in } \\
\text { Higher Education }\end{array}$ & ATEND & + & $\begin{array}{l}\text { Number of places filled in undergraduate } \\
\text { courses at each federal university. }\end{array}$ \\
\hline $\begin{array}{l}\text { University } \\
\text { graduates rate }\end{array}$ & CONCL & + & $\begin{array}{c}\text { Number of graduates in undergraduate courses } \\
\text { at each federal university. }\end{array}$ \\
\hline Personnel expenses & LnPESS & + & $\begin{array}{l}\text { Natural logarithm of total expenses with } \\
\text { active personnel and social charges in federal } \\
\text { universities. }\end{array}$ \\
\hline $\begin{array}{l}\text { Number of } \\
\text { employees }\end{array}$ & FUNC & + & Total number of employees per university. \\
\hline Investments & LnINV & + & $\begin{array}{l}\text { Natural logarithm of investments destined to } \\
\text { the planning and execution of public works and } \\
\text { for the acquisition of permanent installations, } \\
\text { equipment and material. }\end{array}$ \\
\hline
\end{tabular}

Source: Own elaboration (2019)

For the second stage, variables LnGPE, LnPESS e LnINV were featured in natural logarithms, in order to homogenize data throughout the analyzed period. Regarding the LnPESS variable, it is believed that total personnel expenses may affect the variation of Higher Education efficiency. Cunha and Rocha (2012) have used this variable to evaluate the efficiency of public universities in Portugal. Katharaki and Katharakis (2010) have also considered this variable in evaluating efficiency, with a sample of 20 Greek universities. The importance of human resource management is highlighted, as investments in people management bring positive contributions to university performance (KATHARAKI; KATHARAKIS, 2010).

Regarding the number of employees (FUNC), it is assumed that the higher the amount of employees available in each University, the better the service to each university student, and affects the Higher Education efficiency. The studies of Katharaki and Katharakis (2010), Worthington and Lee (2008) have used this variable to measure efficiency, and to analyze the result of the work of professors and administrative staff in universities. 
Agasisti (2014) and Cuellar (2014) state that a higher number of employees involved in Higher Education has a positive relationship with student efficiency and performance. Katharaki and Katharakis (2010) claim that university employees are invaluable to university performance.

Regarding the logarithm of investment in university structure (LnINV), on the other hand, it is assumed that the larger the structure, quality of equipment, and access to essential Higher Education materials, the higher the efficiency level of formation of students regularly enrolled in Higher Education courses (CUNHA; ROCHA, 2012).

\section{Analysis of results}

At first, a descriptive analysis was carried out for the variables comprising both stages throughout the period analysed (see Table 3).

Table 3 - Descriptive statistics of the variables of the first and second stages

\begin{tabular}{lcccc}
\hline Variable & Mean & Standard deviation & Minimum & Maximum \\
\hline GPE & 381.298 .291 & 289.916 .737 & 32.177 .636 & 1.734 .215 .724 \\
PROF & 1.484 & 978 & 135 & 4.179 \\
ATEND & 17.932 & 10.939 & 870 & 49.305 \\
CONCL & 2.063 & 1.401 & - & 6.657 \\
PESS & 295.268 .396 & 225.144 .947 & - & 1.353 .409 .677 \\
FUNC & 3.491 & 2.655 & 233 & 15.259 \\
INV & 9.361 .283 & 9.069 .496 & 33.862 & 55.514 .271 \\
EFI & 0,73 & 0,19 & 0,17 & 1,00 \\
\hline
\end{tabular}

Source: Own elaboration (2019)

The results from Table 3 demonstrate that the public expenditure in Education (GPE) featured great amplitude between the universities analysed, at a minimum amount of $R \$ 32,178.00$ and a maximum amount of $R \$ 1,734,216.00$. The average of expenses was $\mathrm{R} \$ 381,298.00$. The number of professors (PROF) also featured great amplitude, at a minimum amount of 135 and a maximum amount of 4,179, averaging 1,484 professors. The service rate (ATEND) featured a minimum value of 870 and a maximum value of 49,305, a huge gap between amounts. The variables university graduates rate (CONCL), personnel expenses (PESS), number of employees (FUNC), and investments (INV) featured representative standard deviation values if compared to the average, in other words, high dispersion. 
Lastly, the efficiency score of federal universities (EFI) averaged 0.73 . Considering this score is measured between 0 and 1 , with 1 indicating the highest degree of efficiency, it is concluded that, on average, Brazilian federal universities obtained a good efficiency score regarding expenses in Higher Education.

According to the results, the most efficient federal universities, with a score of one over the five periods analyzed, were: Unifap, Ufam and UFPA. Therefore, the three aforementioned universities had the best management practices of public budget for lecturing and graduation activities among all 59 universities analyzed. It should be highlighted that these universities, throughout the periods analyzed, have shown relatively lower public expenditure in comparison to other universities, and attained the best efficiency scores.

An amount of 295 observations was recorded for the period analyzed. Of this amount, 43 observations were found to be efficient. In other words, only $15 \%$ of observations were considered efficient over the years. If the results of the present study are compared to the research from Abbot and Doucouliagos (2003), it is concluded that the results differ regarding the homogeneity in performance over the entire university system.

The efficiency analysis results for federal universities have pointed out that certain universities have maintained efficiency in Higher Education expenses over the years. In 2013, the following universities were efficient: UFU, Unifap, Ufam, UFC, Ufopa, UFPA, UFRJ and UTFPR. In 2014, the following universities were efficient: Unifap, Ufam, UFC, Ufopa, UFPA, UFPE, UFRJ, UFF and UTFPR. In 2015, universities Unir, Unilab, Unifap, Ufam, UFC, UFPA, UFPI, UFRJ and UFF had a high efficiency degree. In 2016, Unifap, Ufam, UFC, UFMA, Ufopa, UFPA, UFF e UFRA were efficient. Lastly, in 2017 universities Unilan, Unifap, Ufam, UFMA, Ufopa, UFPA, UFPI, UFF e UFRRJ were efficient.

This way, by analyzing the variables used for calculating efficiency over the years, the present study supports Athanassopoulos and Shale (1997) regarding university size. The authors state that the size and structure offered by the university are not considered factors relevant enough so that universities attain efficiency.

On the second stage of application of the research method, the efficiency was considered as a dependent variable in the truncated regression model. The following were used as independent variables: public expenditures with Higher Education, in other words, financial amounts for direct spending in the Higher Education subfunction; number of professors; number of enrolments; number 
of graduates; personnel expenses; total number of employees; financial amounts for investments in federal universities.

Due to data inconsistency, and in order to homogenize information, the natural logarithm was applied to carry out the transformation of the variables public expenditure in Education (GPE), personnel expenses (PESS) and expenses with public works, facilities, equipment and permanent material (INV). In addition, the correlation of variables was analysed, in order to detect multicollinearity issues. Although some variables featured a high correlation, the VIF (Variance Inflation Factor) test detected no multicollinearity issues among independent variables used in the model.

This way, data obtained from the Simar and Wilson regression model are featured in Table 4.

Table 4 - Effect of regressors on efficiency

\begin{tabular}{lcccc}
\hline Efficiency & Coefficient & $\begin{array}{c}\text { Standard } \\
\text { error }\end{array}$ & Z & $\begin{array}{c}\text { Significance } \\
(\boldsymbol{p} \text {-value })\end{array}$ \\
\hline EFI & -1.043 .764 & 0.19964 & -5.23 & 0.000 \\
LnGPE & -0.0000972 & $9.29 \mathrm{e}-06$ & -10.47 & 0.000 \\
PROF & 0.0000214 & $2.01 \mathrm{e}-06$ & 10.64 & 0.000 \\
ATEND & 0.0000561 & 0.0000163 & 3.45 & 0.001 \\
CONCL & 0.8606668 & 0.1753472 & 4.91 & 0.000 \\
LnPESS & -0.000068 & $5.54 \mathrm{e}-06$ & -12.27 & 0.000 \\
FUNC & 0.0053987 & 0.0174494 & 0.31 & 0.757 \\
LnINV & 2.133 .176 & 0.4616108 & 4.62 & 0.000 \\
_cons & 0.104947 & 0.0045699 & 22.96 & 0.000 \\
/sigma & 252 & - & - & - \\
\hline Number of observations & 43 & - & - & - \\
Number of eficiente DMUs & 1,000 & - & - & - \\
Number of bootstraps, reps & 373.29 & - & - & - \\
Wald chi2(7) & 0.0000 & - & - & - \\
Prob > chi2(7) & & &
\end{tabular}

Source: Own elaboration (2019)

It should be emphasized that in Table 4 the regression model featured 295 observations, with 43 observations coming from efficient universities and 252 observations from inefficient universities throughout the period analyzed. 
Therefore, only $15 \%$ of observations were efficient. The remaining observations (85\%) refer to inefficient federal universities regarding expenses with Higher Education for graduation classes.

It warrants notice that the determination of expenses within a university is complex, due to the need of allocation of said expenses. In addition, universities are organizations that provide multiple products and results, spread out in lecturing, research and extension categories (KOSHAL; KOSHAL, 1999).

It was found that, in the first stage of this study, some universities with lower amounts of public expenditures attained better performance than universities with a higher expenditure amount. Thus, the findings of the present study support what is pointed out in the study of Katharaki and Katharakis (2010). The authors argue the need of limiting or increasing funding amounts for some universities, taking up management measures to ensure optimal usage of available resources.

The second variable analyzed in the study is the number of professors (PROF), that featured the opposite sign as expected, at $1 \%$ statistical significance level.

The educational service rate (ATEND) positively influences efficiency at a $1 \%$ significance level. For this variable, the sign found is in line with the initially expected sign. The results of the present study for this variable support the study of Cuellar (2014). The author states that the educational service rate is considered an important variable in measuring efficiency, considering it is an important factor in generating human capital, particularly in emerging countries. The author also states that this variable is positively related to the identification of the government's ability to provide Higher Education to its society. In fact, the amount of enrolled students is a key factor in measuring university efficiency (KATHARAKI; KATHARAKIS, 2010).

The university graduates rate (CONCL) has also featured statistical significance at $99 \%$ confidence. The positive sign found in Table 4 indicates that this variable positively influences the efficiency of expenses in Higher Education. This result supports the results found by Katharaki and Katharakis (2010). In other words, the number of graduates (university graduates) positively impacts the efficiency results of university expenditures.

Another variable used in the regression model sis the personnel expenses (LnPESS), represented in the present study by the total of expenses with active personnel and social charges in federal universities for each year analysed. Upon analysis 
of the behavior found for this variable, it may be stated that the total amount of personnel expenses positively affects the efficiency of federal universities. In addition, the sign found for this variable is in line with the expected sign. The variable featured statistical significance at a $1 \%$ significance level.

Results found support the studies of Worthington and Lee (2008), considering the importance of this variable in university efficiency. Thus, investment in human resource management positively impacts in the performance and efficiency of universities.

Worthington and Lee (2008) explain that the human resources of universities analyzed positively impact the efficiency regarding the amount of undergraduate and graduate students. This way, the authors' findings support the results of the present study for the LnPESS variable.

Another regression model variable related to personnel management refers to the amount of employees (FUNC), defined as the total amount of employees at each university. The variable has shown opposite sign in comparison to initial expectations, and featured statistical significance at a $99 \%$ confidence level. Results found in the present study differ from the studies of Agasisti (2014) and Cuellar (2014).

Whereas the variable expenses with public works, facilities, equipment and permanent material (LnINV) featured a positive sign, but with no statistical significance identified for this variable, distinct from similar studies. Cunha and Rocha (2012) have identified positive and significant signs, and found out that the higher the investment in university structure, higher quality equipment, and higher access to essential Higher Education materials, the higher the efficiency level in the formation of students regularly enrolled in Higher Education courses.

One of the reasons for this result of the LnINV may be guided by the study of Worthington and Lee (2008). The authors emphasize that public universities need to improve their internal income generation, as to reduce government dependency. The authors also highlight that an improvement in income generation will facilitate growth, as well as increasing investments in universities.

The behavior of the LnINV shows the need for better monitoring of infrastructure investments of federal universities from public managers. Upon analysis of the information from Tables 3 and 4, the disparity in expenses with public works, facilities, equipment and permanent materials should be highlighted. As a solution, 
Katharaki and Katharakis (2010) suggest limiting or increasing public funding available for universities based on efficiency scores, enabling public managers to adopt management measures to ensure optimal usage of available resources. In addition, it becomes necessary that managers adopt long-term planning measures for federal universities. According to the study from Gralka (2018), an increase in efficiency for universities is only possible if the measures adopted consider long-term management policies.

\section{Final considerations}

This research explained the determining factors in efficiency of public expenditures in federal universities from 2013 to 2017. The study has demonstrated that most federal universities analyzed are still inefficient in allocating public expenditures. In certain observed cases, even with higher public expenditures in Higher Education than the average of federal universities, the university featured inferior results. The same was observed regarding number of professors. Some universities featured a number of professors higher than the average of universities and featured lower results (outputs) when compared to other universities. In such cases, the universities featured efficiency scores lower when compared to other universities.

We found that some federal universities featured a maximum efficiency score, such as Unifap, Ufam and UFPA. These universities were efficient during the five years analyzed, and may serve as reference for other universities to improve their spending with Higher Education.

Results of the truncated regression model show that the variables LnGPE, PROF, ATEND, CONL, LnPESS and FUNC have statistical significance at 99\% confidence, with a $1 \%$ error margin.

Considering the results of the present study, benefits are provided to the public managers of the federal universities analyzed, to the population segment that is interested in monitoring the management of federal universities. The results of this study may be understood as quality indicators of public spending in Higher Education undergraduate courses.

This study opens a discussion about the results of this study and about this subject is extremely relevant, in face of a scenario of budget restrictions in Brazilian Higher Education. With such results, it is expected that some measures are applied for constraining public managers in order to render Brazilian Higher Education more efficient. Studies with application of the Simar and Wilson regression method 
(2007) to Higher Education are still rare, in order to analyze the efficiency of public spending in universities. In academic studies with Brazilian data, this is a landmark study. Future studies may incorporate new variables to the expenditure efficiency analysis model in Higher Education.

Future studies on the analysis of key factors in efficiency of federal universities may contribute to the improvement of management of public resources in universities. The results of this study may enable identification of universities to be considered as reference in correct use of resources. In addition, efficiency scores were generated in order to create a spending efficiency rank. In addition, based on the truncated regression model, it was possible to observe the impact that each of the variables has in Higher Education spending efficiency.

Lastly, it should be noted that results and conclusions developed thereof in the present study should be interpreted considering the features referring to methodologies adopted, universities analyzed and time period. Future studies may include new variables, considering the influence of social, cultural and economic factors. 


\section{A eficiência dos gastos públicos no Ensino Superior: um estudo com Universidades Federais brasileiras}

\section{Resumo}

Este estudo tem como objetivo descrever os fatores determinantes na eficiência dos gastos públicos em Universidades Federais Brasileiras. Foi aplicado um método de pesquisa em duas etapas para uma amostra de 59 Universidades Federais Brasileiras, de 2013 a 2017. A Análise Envoltória de Dados (DEA) foi aplicada na primeira etapa para medir a eficiência dos gastos públicos. Para a segunda etapa, foi aplicado um modelo de regressão truncado, juntamente com um procedimento de bootstrap duplo para correção do viés e teste de significância estatística das variáveis. Os resultados mostram que algumas Universidades Federais foram ineficientes nesse periodo. Considerando o modelo de regressão truncado de Simar e Wilson (2007), variáveis significativas que influenciam a eficiência dos gastos públicos nas Universidades Federais foram gastos públicos no Ensino Superior, quantidade de professores, quantidade de matrículas, quantidade de graduados, despesas totais com funcionários e quantidade total de funcionários. Diante disso, o estudo contribuiu para a literatura científica, pois demonstra que essas variáveis são fundamentais para a eficiência pública nas Universidades Federais.

Palavras-chave: Eficiência de Gastos Públicos. Bootstrapp Duplo. Ensino Superior. Análise Envoltória de Dados. Regressão Truncada.

\section{La eficiencia del gasto público en Educación Superior: un estudio con Universidades Federales brasileñas}

\section{Resumen}

Este estudio tiene como objetivo describir los factores determinantes en la eficiencia del gasto público en las universidades brasileñas. Se aplicó un método de encuesta en dos etapas para una muestra de 59 instituciones de educación superior, de 2013 a 2017. El Análisis de Envolvimiento de Datos (DEA) se aplicó en la primera etapa para medir la eficiencia del gasto público. Para la segunda etapa, se aplicó un modelo de regresión truncado, junto con un procedimiento de arranque doble para la corrección del sesgo y la prueba de significación estadística de las variables. Los resultados muestran que algunas universidades brasileñas fueron ineficientes durante este perodo. Considerando el modelo de regresión truncado de Simar y Wilson (2007), las variables significativas que influyen en la eficiencia del gasto público en las Universidades Federales fueron los gastos públicos en Educación Superior, la cantidad de docentes, la cantidad de matrículas, la cantidad de graduados, los gastos totales con empleados y el total cantidad de empleados. A la luz de esto, el estudio ha contribuido a la literatura cientifica, ya que demuestra que tales variables son clave para la eficiencia pública en las Universidades Federales.

Palabras clave: Eficiencia del Gasto Público. Arranque Doble. Educación Superior. Análisis de Envolvimiento de Datos. Regresión Truncada. 


\section{References}

ABBOTT, M.; DOUCOULIAGOS, C. The efficiency of Australian universities: a data envelopment analysis. Economics of Education Review, Cambridge, v. 22, n. 1, p. 89-97, Feb. 2003. https://doi.org/10.1016/S0272-7757(01)00068-1

AFONSO, A.; AUBYN, S. M. Cross-country efficiency of secondary education provision: a semi-parametric analysis with non-discretionary inputs. Economic Modelling, London, v. 23, n. 3, p. 476-491, May 2006. https://doi.org/10.1016/j.econmod.2006.02.003

AFONSO, A., FERNANDES, S. Assessing and explaining the relative efficiency of local government. The Journal of Socio-Economics, Greenwich, v. 37, n. 5, p. 1946-1979, Oct. 2008. https://doi.org/10.1016/j.socec.2007.03.007

AGASISTI, T. The efficiency of public spending on education: an empirical comparison of EU countries. European Journal of Education, London, v. 49, n. 4, p. 543-557, Dec. 2014. https://doi.org/10.1111/ejed.12069

AGASISTI, T.; PÉREZ-ESPARRELLS, C. Comparing efficiency in a cross-country perspective: the case of Italian and Spanish state universities. Higher Education, [s. 1.], v. 59, n. 1, p. 85-103, Jan. 2010. https://doi.org/10.1007/s10734-009-9235-8

ARCELUS, F. J.; COLEMAN, D. An efficiency review of university departments. International Journal of Systems Science, London, v. 28, n. 7 , p. 721-729, Jul. 1997. https://doi.org/10.1080/00207729708929431

ATHANASSOPOULOS, A. D.; SHALE, E. Assessing the comparative efficiency of higher education institutions in the UK by the means of data envelopment analysis. Education Economics, London, v. 5, n. 2, p. 117-134, 1997. https://doi.org/10.1080/09645299700000011

CHARNES, A.; COOPER, W; RHODES, E. Measuring the efficiency of decision- making units. European Journal of Operational Research, Amsterdam, v. 2, n. 6, p. 429-444, Nov. 1978. https://doi.org/10.1016/0377-2217(78)90138-8

COCO, G.; LAGRAVINESE, R. Cronyism and education performance. Economic Modelling, London, v. 38, n. 1, p. 443-450, Feb. 2014. https://doi.org/10.1016/j.econmod.2014.01.027 
CUELLAR, A. F. S. The efficiency of education expenditure in Latin America and lessons for Colombia la eficiencia del gasto público educativo en Latinoamérica y lecciones para Colombia. Desarrollo y Sociedad, Bogotá, v. 74, n. 1, p. 19-67, Segundo semestre 2014. Available from: https://revistas.uniandes.edu.co/doi/pdf/10.13043/dys.74.1. Access: 2020 Apr. 25.

CUNHA, M.; ROCHA, V. On the efficiency of public higher education institutions in Portugal: an exploratory study. FEP Working Paper, Porto, n. 468, July 2012. Available from: http://wps.fep.up.pt/wps/wp468.pdf. Access: 2020 Apr. 15.

DUFRECHOU, P. A. The efficiency of public education spending in Latin America: a comparison to high-income countries. International Journal of Educational Development, London, v. 48, n. 1, p. 188-203, July 2016. https://doi.org/10.1016/j.ijedudev.2016.03.005

FARRELL, M. J. The measurement of productive efficiency. Journal of the Royal Statistical Society. Series A (General), London, v. 120, n. 3, p. 253-290, 1957. https://www.jstor.org/stable/2343100

FLACH, L.; ANTONELLO, C. S. Organizações culturais e a aprendizagem baseada em práticas. Cadernos EBAPE.BR, Rio de Janeiro, v. 9, n. 1, p. 155-175, mar. 2011. https://doi.org/10.1590/S1679-39512011000100010

GRALKA, S. Persistent inefficiency in the higher education sector: Evidence from Germany. Education Economics, London, v. 19, n. 1, p. 1-20, Jan. 2018. https://doi.org/10.1080/09645292.2017.1420754

GRAMANI, M. C. N.; DUARTE, A. L. C. M. O impacto do desempenho das instituições de educação básica na qualidade do ensino superior. Ensaio: Avaliação e Políticas Públicas em Educação, Rio de Janeiro, v. 19, n. 72, p. 679-702, jul./set. 2011. https://doi.org/10.1590/S0104-40362011000400011

GUDOLLE, L. S.; ANTONELLO, C. S.; FLACH, L. Aprendizagem situada, participação e legitimidade nas práticas de trabalho. RAM. Revista de Administração Mackenzie, São Paulo, v. 13, p. 14-39, jan./fev. 2012. https://doi.org/10.1590/S1678-69712012000100002

HANUSHEK, E. A.; WOESSMANN, L. How much do educational outcomes matter in OECD countries? Economic Policy, v. 26, n. 67, p. 427-491, July 2011. https://doi.org/10.1111/j.1468-0327.2011.00265.x 
JOHNES, J. Data envelopment analysis and its application to the measurement of efficiency in higher education. Economics of Education Review, Cambridge, v. 25, n. 3, p. 273-288, June 2006. https://doi.org/10.1016/j.econedurev.2005.02.005

JOHNES, J. Efficiency and productivity change in the English higher education sector from 1996/97 to 2004/5. The Manchester School, v. 76, n. 6, p. 653-674, Oct. 2008. https://doi.org/10.1111/j.1467-9957.2008.01087.x

JOUMADY, O.; RIS, R. Performance in European higher education: A non-parametric production frontier approach. Education Economics, London, v. 13, n. 2, p. 189-205, Feb. 2005. https://doi.org/10.1080/09645290500031215

KATHARAKI, M.; KATHARAKIS, G. A comparative assessment of Greek universities' efficiency using quantitative analysis. International Journal of Educational Research, Oxford, v. 49, n. 4, p. 115-128, 2010. http://dx.doi.org/10.1016/j.ijer.2010.11.001

KEMPKES, G.; POHL, C. The efficiency of German universities: some evidence from nonparametric and parametric methods. Applied Economics, London, v. 42, n. 16, p. 2063-2079, June 2010. https://doi.org/10.1080/00036840701765361

KOSHAL, R. K.; KOSHAL, M. Economies of scale and scope in higher education: a case of comprehensive universities. Economics of Education Review, Cambridge, v. 18, 2, p. 269-277, Apr. 1999. https://doi.org/10.1016/S0272-7757(98)00035-1

MIKUŠOVÁ, P. Measuring the efficiency of the Czech public higher education institutions: an application of DEA. Journal on Efficiency and Responsibility in Education and Science, Prague, v. 10, n. 2, p. 58-63, June 2017. https://doi.org/10.7160/eriesj.2017.100204

SALERNO, C. Using data envelopment analysis to improve estimates of higher education institution's per-student education costs. Education Economics, London, v. 14, n. 3, p. 281-295, Feb. 2006. https://doi.org/10.1080/09645290600777485

SAV, G. T. Efficiency evaluations of US Public Higher Education and effects of state funding and pell grants: panel data estimates using two stage data envelopment analysis, 2004-2013 academic years. Journal of Education Finance, Champaigne, v. 42, n. 4, p. 357-385, Spring 2017. https://muse.jhu.edu/article/668214

SIMAR, S.; WILSON, P. W. Estimation and inference in two-stage, semiparametric models of production processes. Journal of Econometrics, Amsterdam, v. 136, n. 1, p. 31-64, Jan. 2007. https://doi.org/10.1016/j.jeconom.2005.07.009 
TEDESCO, J. C.; LÓPEZ, N. Las condiciones de educabilidad de los niños y adolescentes em América Latina. Buenos Aires: IIEP-UNESCO Regional Office, 2002.

WHEELOCK, D. C.; WILSON, P. W. Non-parametric, unconditional quantile estimation for efficiency analysis with an application to Federal Reserve check processing operations. Journal of Econometrics, Amsterdam, v. 145, n. 2, p. 209-225, July 2008. https://doi.org/10.1016/j.jeconom.2008.05.007

WOLSZCZAK-DERLACZ, J. An evaluation and explanation of (in) efficiency in higher education institutions in Europe and the US with the application of two-stage semi-parametric DEA. Research Policy, Amsterdam, v. 46, n. 9, p. 1595-1605, Nov. 2017. https://doi.org/10.1016/j.respol.2017.07.010

WOLSZCZAK-DERLACZ, J.; PARTEKA, A. Efficiency of European public higher education institutions: a two-stage multicountry approach. Scientometrics, Amsterdam, v. 89, n. 3, p. 887-917, Aug. 2011. https://dx.doi.org/10.1007\%2Fs11192-011-0484-9

WORTHINGTON, A. C.; LEE, B. L. Efficiency, technology and productivity change in Australian universities, 1998-2003. Economics of Education Review, Cambridge, v. 27, n. 3, p. 285-298, June 2008. https://doi.org/10.1016/j.econedurev.2006.09.012

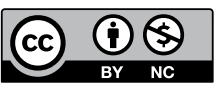

\section{Information about authors}

David Daniel Hammes Junior: Accounting Professor at Faculty of Technology Nova Palhoça/Unigranrio, Brazil. Contact: juniorhammes@yahoo.com.br

iD https://orcid.org/0000-0002-0445-2026

Leonardo Flach: Professor at Federal University of Santa Catarina, Brazil.Post doctoral in Accounting and Finance at Massachusetts Institute of Technology (MIT/USA). PhD in Administration at Federal University of Rio Grande do Sul, Brazil. Contact: leonardo. flach@gmail.com

iD https://orcid.org/0000-0002-4316-0704

Luísa Karam de Mattos: PhD Student in Administration at Federal University of Santa Catarina, Brazil. Contact: luisakmattos@gmail.com

(iD) https://orcid.org/0000-0003-1990-3034 